Uniwersytet Przyrodniczo-

Humanistyczny w Siedlcach

Siedlce University of Natural

Sciences and Humanities

https://bazawiedzy.uph.edu.pl

\begin{tabular}{|l|l|}
\hline Publikacja / Publication & $\begin{array}{l}\text { Educational reality in Comenius' views: the content aspect of comeniology, } \\
\text { Florczykiewicz Janina }\end{array}$ \\
\hline $\begin{array}{l}\text { Adres publikacji w Repozytorium URL } \\
\text { / Publication address in Repository }\end{array}$ & https://bazawiedzy.uph.edu.pl/info/article/UPH96f9209dbe8e41f6ab0ae53eaf60abc0/ \\
\hline $\begin{array}{l}\text { Data opublikowania w Repozytorium / } \\
\text { Deposited in Repository on }\end{array}$ & Oct 22, 2021 \\
\hline Rodzaj licencji / Type of licence & Attribution-NoDerivs (CC BY-ND 3.0) \\
\hline Cytuj tę wersję / Cite this version & $\begin{array}{l}\text { Florczykiewicz Janina: Educational reality in Comenius' views: the content aspect } \\
\text { of comeniology, Siedleckie Zeszyty Komeniologiczne seria PEDAGOGIKA, no. 6, } \\
2019, \text { pp. 91-99 }\end{array}$ \\
\hline
\end{tabular}




\title{
EDUCATIONAL REALITY IN COMENIUS' VIEWS - THE CONTENT ASPECT OF COMENIOLOGY
}

DOI: $10.5604 / 01.3001 .0013 .6246$

\begin{abstract}
The text proposes an approach to comeniology in the subjective perspective focusing on the content dimension of the research process. The considerations were based on the approach to science presented in Polish literature as a system of theorems about reality developed in the course of research. Comenius' work is considered from the perspective of the description of educational reality contained in it, which is composed of his concept of education. The intention was to present truths about the world, man and relations between them, objectively recognized by the author. The views on the concept of man, teacher and upbringing were reconstructed. A description of the educational reality outlined by the author was presented, taking into account the three elements constituting it - the concept of man, upbringing and teacher. The intention was only to mention the most relevant content, because an exhaustive discussion goes beyond the scope of the article.
\end{abstract}

Keywords: comeniology, content aspects of science, educational reality

The universalism of the theses proclaimed by Jan Amos Comenius, considered as one of the founders of modern pedagogy, contributes to the unwavering interest in his pedagogical thought, still persisting in modern times, as evidenced by the creation and publication of Siedlce Comeniology Notebooks.

As Sitarska (2014a) writes, "Knowledge and reception of Comenius 'works in Poland began during Comenius' lifetime and at the same time when his works appeared in print (Leszno, Gdańsk)" (p. 51) and is undoubtedly the result of his over 20 years long stay in Poland - in Leszno (Szymańska, 2014). Numerous studies on Comenius' theses contributed to the emergence of an independent research direction - comeniology.

The term comeniology itself, as Sitarska (2014a) indicates, has not been clearly defined. The author suggests that it should be understood as a 
science whose subject is life, public activity (scientific, political, educational) and the body of work of Comenius.

Sławomir Sztobryn (2017) reports that the beginning of scientific comeniology in Poland falls in the 19th century and is related to his scientific legacy. As part of comeniology, both biographical and substantive analyzes are undertaken, referring to the views expressed by Comenius. "Within these studies, specializations are slowly emerging: issues of broadly understood pedagogical thought (interpretations of Comenius' works), as well as Comenius' philosophy, his views on the human world and the natural world." (Sztobryn 2017: 52)

The term comeniology can be considered not only through the theoretical studies of the life and pedagogical thought of Jan Amos Comenius. Comeniology can be approached in terms of practicing science, i.e. through the len of the activities undertaken by the researcher and their specific effects. This way of understanding is consistent with the approach of science proposed by Kazimierz Ajdukiewicz, who accepts that science is a product of the researcher's activities in the form of "the system of theorems that scholars have recognized in their quest to learn reality" (Ajdukiewicz, 1965: 173). Therefore, referring to the concept of science by Jerzy Apanowicz (2002) that it includes activities aimed at learning about reality, arising from the needs of its mastery and transformation. In this sense, comeniology would consist of the research process, its results and their presentation. Science reveals itself in two aspects - substantial and functional. The substantial aspect includes a system of justified concepts, theorems and hypotheses containing objective knowledge adequate to a given stage of development of scientific cognition. This knowledge, related to objects, structures, dependencies of processes and regularities within a given discipline is a product of scientific and research activity (functional aspect of knowledge) (Ajdukiewicz, 1965: 173).

Therefore, looking at Comenius' body of work through the prism of science, as Sztobryn (2017) suggests, one can emphasize its content aspects by exposing the system of theorems describing a specific fragment of reality or functional aspects including procedures (scientific and research activities) undertaken by the author to describe reality, i.e. referring to to the research (syncritical) method he proposed. The content aspect is crucial for knowledge, hence further considerations focus on it.

Reflections on education play an important role in Comenius' legacy. They are the foundation for a description of the social world in its various philosophical connotations. Reflections on the nature and determination of a 
man (child) and the world, the relationships between them, their genesis and regularities make up the description of educational reality, which can be described as educational. This trend of issues has become an important area of inquiry for comeniologists. Later in this study, a reconstruction of the description of educational reality outlined by Comenius was undertaken. Potentially it can become a starting point to show the evolution of views that has taken place since the time of this scholar.

Before discussing the indicated issue, one should refer to the very concept of reality, which, as Sztobryn (2013) emphasizes, is an ambiguous category, and its meaning depends on the context. Author positions the act of constructing the theory undertaken on the basis of historiography, which, referring partly to the empirically observable reality, is at the same time its potential project in existing reality. Educational reality is therefore defined by Sztobryn (2013: 19) as a material, intelligent being or synthesis of the two, independent of the cognitive subject, but perceived by this subject as present in experience and reflection.

By adopting this point of view, the views on upbringing included in Comenius' works, contributing to the history of pedagogical thought, will be treated as part of the educational reality he outlined. Their reconstruction assumes the character of narrative history and falls within the scope of historical pedagogy, which Sztobryn describes as "the creative (de) (re)construction of the historical process woven from available sources, from internalized knowledge and imagination filling the gaps between factual data." (Sztobryn, 2013: 20). Historical pedagogy refers to a specific research methodology. It is a conscious and deliberate reflection on the past, which includes giving meaning to events that model the past (ibid.). The educational reality described on the basis of historical pedagogy is relative, and its meaning depends on the context defined by the narrative structure.

Educational reality is determined by overlapping elements, i.e. 1) adopted ideology expressed in the objectives, content and educational tasks, which reflects the standards adopted in the country and the beneficiaries of the education process, i.e. 2) students and their educational needs, and 3) teachers and their teaching workshop. All these were referred in Comenius' reflections, illustrating his way of thinking about the world.

In Comenius' concept of world and man a theological orientation, shaped in the aftermath of theological education and worldview can be observed. His work "consistently touches the sphere of the sacred, that is, what is associated with God, the Holy Trinity, or transcendental reality" 
(Szymonik, 2012: 232, after: Sitarska, 2014) And this sphere becomes the reference point in his views on education. The starting point for building knowledge about the world is man - his nature and orientation towards God. The author makes God and his wisdom (omniscience) the ultimate goal of human aspirations. The outlined concept refers to the theological dogma of man created in the image of God, hence his development is perceived in terms of approaching the divinity expressed in omniscience: "Man is born with the ability to learn about things primarily because he is made in an image of God [...]. Therefore, since God's omniscience stands out among God's other qualities, so must man's radiance reflect in a way" (Comenius, 1956: 44).

The humanistic orientation which is the legacy of renaissance thought found expression in the focus on man, on its basis the author consistently developed the anthropological concept of education, which is characterized by the integration of philosophical and pedagogical thought (Čapkova 1997: 41-50, after: Sitarska 2014 b).

\section{Concept of man}

In keeping with the Christian doctrine, Comenius assumed that "the ultimate goal of man is eternal happiness in communication with God," (Comenius, 1956: 39) while earthly life (on earth) is assigned specific goals pursued through education, virtue or noble customs and religiousness. Their makings are assigned to man by nature, but they require development education. (cf. Comenius,1956: 41-43).

Comenius perceived the child as an unformed being, indefinite in humanity, endowed with potencies that require the provision of appropriate stimulation and knowledge: "As we have seen, germs of knowledge, honesty, religion are given by nature; but knowledge, virtue and religion alone are not given; it is achieved through prayer, learning and acting. "This assumption implies the necessity of influencing and shaping the child. Education becomes a developmental necessity: "Everyone who is born human needs education", the strength constituting humanity, and at the same time giving an advantage over others: "Let no one believe that someone could really be human if he did not learn to act as man; that is, if he was not educated in what makes him human".

Further assumptions relate to innate potencies of man. Comenius claimed that wisdom given by God inherently belongs to him - "every man is born with the ability to gain knowledge about things" (Comenius, 1956: 44) 
and the urge to knowledge. The author believes in the unlimited possibilities of the mind in building knowledge: "Our thought not only catches the near, but also brings closer to what is distant (whether in space or time), it rises up towards what sublime, tracks what is latent, reveals what is hidden, even tries to explore the unfathomable; so far unlimited and endless" (Comenius, 1956: 44). This ability makes it possible to achieve the goal of life set for people eternity. Therefore, wisdom is a typically human potency, which enables us to reach a part of divine knowledge, the so-called omniscience, but also defines the peculiar privilege and advantage of man in the world (Florczykiewicz 2016): "Sufficient superiority (...) of people is that they have received mental acuity with which they can follow God's works and thus accumulate the treasury of knowledge." (Comenius, 1956: 57). Experience and observation related to the senses allow full knowledge of the world. Omniscience is available to people to varying degrees, according to Sztobryn (2015), "there are individual differences between people who can become wise in terms given to them by nature, but not equally available" (p. 93-94).

Adolescence is considered by Comenius to be the most important for upbringing, he places the greatest hopes in it, combining them with openness to experience and the ability to absorb knowledge: "In order for man to develop into man, God gave him years of youth in which he lives (...) only able to shape himself" (p. 65).

As noted by Suchodolski „To tylko w człowieku jest silne i trwałe, czym nasiąknie najwcześniejsze dzieciństwo" (p. 66), the concept of human nature outlined by Comenius referred to developmental potencies, understood as an internal orientation to overcoming one's own weaknesses and striving for perfection through the development of mental and physical skills, in which we discover echoes of humanistic ideas. Man was seen in the perspective of transformation and development (Sztobryn, 2015).

\section{The concept of upbringing}

In his assumptions Comenius started with man and pointed to the need to develop his humanity - which is clearly expressed in the title of Chapter VI of "Great Teaching": "If man is to become a man, he must be educated." (Comenius, 1956: 56). The author does not separate upbringing and education. He treats them as a permanent process of acquiring knowledge, i.e. education, lasting from early childhood, at least until adulthood, and actually to death. Comenius' views on upbringing, which are 
a kind of theory of upbringing, were included in his work entitled "Pampaedia". We find in them a number of innovative and even revolutionary theories. One of them, already announced in the subtitle of the work, promotes the current idea of upbringing / education throughout life. Comenius sets seven periods of life from birth to death and seven corresponding schools, assigning educational goals to each of them. They correspond to the level of development and human experience, which reflects the principle of individualisation of education and its adaptation to development needs. (Comenius, 1973: 103). Upbringing is treated as a process of liberating humanity covering the whole of life, this process is necessary because "without upbringing one cannot become a human being" (Comenius, 1956: 56).

Comenius's theory of education contains the necessary postulates relating to the nature, goals, content and methods. According to Comenius, education should be universal, which he expressed in the words: "It is desirable that everyone learn everything completely and entirely." This is the postulate of "full education of a full man" (Comenius, 1973: 9) or attainment of omniscience. According to the author's views, its manifestation was to be a comprehensive culture, i.e. a state in which nothing is missing1, meaning the full level of development in all areas of humanity, called omniscience by the author. It includes knowledge of the physical and social world and the regularities that govern them, especially those related to thinking, communication and social relations, as well as the ability to objectively interpret situations and events based on knowledge rather than prejudices or emotions (cf. Comenius, 1973: 12-13).

Comenius postulated demonstrative teaching based on observation of nature. He wanted the child to derive knowledge not so much from books and words, "but from heaven, earth, oaks and beeches", so that he came to knowledge by learning the things themselves, not the perceptions and testimonies of others. (Sitarska, 2013: 406). He also appreciated the role of books and other teaching resources, and in chapter six of Pampaedia included guidelines for their preparation, including editorial work according to the principles of the universal method. He formulated didactic principles and methods that were to approximate the achievement of the goals of upbringing. He also referred to the school's climate, ensuring that the school

\footnotetext{
${ }^{1}$ Comenius refers to the terms describing the state of education - "everything", "something" and "nothing", explained in "Janua rerum". The term 'everything' means something that is not lacking anything, 'something' refers to partial deficiencies and 'nothing' means the lack of everything (Comenius, 1973: 9, footnote 2).
} 
would become a student-friendly environment, which would optimize education. Among the teaching principles he mentioned "the freedom to make everything pleasant and cheerful as if in play, so that the teaching of people could be called school-fun" (Comenius, 1973: 109).

Comenius' philosophy of upbringing and education is characterized by high radicalism, which goes beyond the views of the time, examples are the postulates of the human right to education, emphasizing the ability to selfeducate and self-raise (Sitarska, 2014) or the postulate of universality of education, which through the idea of uniformity of the program for all learners was an expression of opposition to elite education (Suchodolski, 1956). Educational slogans are saturated with humanism, we find in them postulates proclaimed today by positive psychology and relating to ensuring mental well-being, which is the equivalent of happiness. Comenius postulates: "It is necessary to lead people to satisfy all their desires. They need to awaken the natural urge to feed their desires. Show them the way to make them come true (...)" (Comenius, 1973: 44).

Comenius did not stop at formulating theoretical postulates, they became the starting point for developing the concept of an education system covering the entirety of human life, setting up educational and didactic tasks for each stage.

\section{Teacher concept}

Comenius' views about the teacher are interwoven with the later developed trend of reflecting on the personality of the teacher. In "Pampaedia" we find a comprehensive argument about the characteristics and competences of the teacher. The basic postulate refers to establishing a personal pattern: "that each of them should be the way they are meant to make others", "which we would like all humanity to become (Comenius, 1973: 107). The importance should be attached to educational and didactic competences, which consist of knowledge and skills in the field of organization of upbringing and education, including knowledge of goals, means and methods: "they should know: all the goals of their vocation, all means that lead to them, and any variety of methods" (Comenius 1973: 107). The author also emphasizes the role of teacher's involvement as a factor conditioning the effectiveness of education.

Some aspects of the teacher idealized by Comenius are still valid today. In his image, the teacher is a student-friendly person, engaged in his 
development, treating the student subjectively: "Teachers: if they are approachable and polite, if they do not discourage other minds with any roughness, but attract them with fatherly feeling, behavior and word, (...) if they treat students cordially, they will easily win their hearts, so that the children will probably be more happy to be at school than at home" (Comenius, 1956: 139).

\section{Conclusion}

The educational reality mentioned above, outlined in Comenius' works is an exemplification of his views on upbringing, resulting from the urge repair it, which in turn the author associated with repair of the world (cf. Suchodolski 1956: LX). It is an intentional reality, outlined in the author's concept of the vision of man and the ways of his development/upbringing, including institutional education. In the formal sense, the description created by Comenius includes a system of concepts, theses, and substantiated statements based on objective knowledge adequate to his time, thus meeting the conditions of science in terms of content.

Comenius intended his description to become the basis for formulating basic theorems for the practice of upbringing. Some of them, including. postulates of universality of education, individualization, focus on human development and didactic principles formulated by him, were applied in later times, creating an objective educational reality.

The scope of the current realization of Comenius' pedagogical vision is therefore an important subject of research - his pedagogical thought defining the idea of educational reality nowadays is the source material for studies on determining the current reality.

\section{References}

Ajdukiewicz Kazimierz, Logika pragmatyczna, Warszawa 1965.

Apanowicz Jerzy, Metodologia ogólna, Gdynia 2002.

Čapková Dagmar, Nékteré základni principy pedagogického myšleni J.A. Komenského, In: T. Bieńkowski (ed.), Komeński a współczesność, Wrocław-Warszawa-Kraków-Gdańsk, 1997, p. 41-50.

Florczykiewicz Janina, Drogi prowadzące do wiedzy o człowieku i otaczającym go świecie w twórczości Jana Amosa Komeńskiego, In: B. Sitarska (ed.), Jan Amos Komeński - współczesne interpretacje i reinterpretacje jego 
twórczości, „Siedleckie Zeszyty Komeniologiczne, seria pedagogika”, vol. III, Siedlce 2016, p. 53-62.

Komeński Jan Amos, Pampaedia, Wrocław 1973.

Komeński Jan Amos, Wielka dydaktyka, Wrocław 1956.

Sitarska Barbara, O Janie Amosie Komeńskim i poczq̨tkach komeniologii, In: B. Sitarska (ed.), O Janie Amosie Komeńskim i jego poglądach na edukację, „Siedleckie Zeszyty Komeniologiczne, seria pedagogika”, vol. I, Siedlce 2014a, p. 31-61.

Sitarska Barbara, Humanizm Jana Amosa Komeńskiego, w: B. Sitarska (ed.), O Janie Amosie Komeńskim i jego poglądach na edukację, „Siedleckie Zeszyty Komeniologiczne, seria pedagogika”, vol. I, Siedlce 2014b, p. 149-173.

Sitarska Barbara, Wychowanie i samowychowanie w myśli filozoficznej Jana Amosa Komeńskiego, In: B. Sitarska (ed.), o Janie Amosie Komeńskim i jego poglądach na edukację, „Siedleckie Zeszyty Komeniologiczne, seria pedagogika", vol. I, Siedlce 2014c, p. 119-140.

Sitarska Barbara, Samowychowanie $w$ myśli filozoficznej Jana Amosa Komeńskiego na tle poglądów wybranych myślicieli, In: M. Burta, M. Kryszczuk, S. Sobieraj (ed.), Między człowiekiem i człowiekiem, Siedlce 2013, p. 401-408.

Suchodolski Bogdan, Wstęp, In: Jan Amos Komeński, Wielka dydaktyka, Wrocław 1956.

Szymańska Kamila, Komeński w Lesznie, In: B. Sitarska (ed.), o Janie Amosie Komeńskim i jego poglądach na edukację, „Siedleckie Zeszyty Komeniologiczne, seria pedagogika" vol. I, Siedlce 2014a, p. 301-308.

Sztobryn Sławomir, Polska XX-wieczna recepcja pedagogiki Jana Amosa Komeńskiego, In: B. Sitarska, Współczesne recepcje Jana Amosa Komeńskiego, „Siedleckie Zeszyty Komeniologiczne, seria pedagogika”, vol. IV, Siedlce 201, p. 57-72.

Sztobryn Sławomir, Jan Amos Komeński (1592-1670) jako przedstawiciel nowożytnej filozofii wychowania, In: B. Sitarska (red.), Jan Amos Komeński - jego pedagogika i filozofia, „Siedleckie Zeszyty Komeniologiczne, seria pedagogika", vol. II, Siedlce 2015, p. 91-100.

Sztobryn Sławomir, Rzeczywiste i nierzeczywiste w edukacji w kontekście narracji historycznej, In: S. Sztobryn, K. Kamiński (ed.), Rzeczywistość edukacyjna. Tropy i wątki interpretacyjne, Łódź 2013.

Szymonik Danuta, $Z$ zagadnień sakrum w wybranych utworach Jana Amosa Komeńskiego/Über das „Sacrum” in den ausgewählten Werken von Jan Amos Komenský, In: B. Sitarska, R. Mnich (ed.), „Studia Comeniana Sedlcensia" Jan Amos Komeński a Europa XVII wieku/ Jan Amos Komenský und Europa im XVII. Jahrhundert, vol. IV, Siedlce 2012, p. 214223. 